\title{
Influence of Conventional and Intensive Cropping Sequences on Wheat Productivity under Different Mineral Nitrogen Fertilizer Rates
}

\author{
Saad H. Abo-Khadra ${ }^{1}$, Sobhy G.R.Sorour ${ }^{1}$, Salah E.A. Toaima ${ }^{2}$ and \\ Dina E.E.El-Sherief ${ }^{2}$ \\ ${ }^{1}$ Agronomy Department, Faculty of Agriculture, Kafr El-Shiekh Uiversity, Egypt. \\ ${ }^{2}$ Crop Intensification Research Department, Field Crops Research Institute, Agricultural Research \\ Center, Egypt.
}

\begin{abstract}
A two-year study was conducted at Sakha Research station, Agricultural Research Center (ARC), Kafr El-Shiekh governorate, Egypt during 2013/2014 and 2014/2015 to decrease mineral nitrogen (N) inputs of wheat crop. This study included two experiments each one contained 9 treatments, which were combinations of three cropping sequences (summer crop/Egyptian clover "fahl"/wheat, summer crop/fodder maize/wheat and summer crop/fallow/wheat) and three mineral $\mathrm{N}$ fertilizer rates $(80 \mathrm{~kg} \mathrm{~N} / \mathrm{fad}, 60 \mathrm{~kg} \mathrm{~N} / \mathrm{fad}+$ ascobien and $40 \mathrm{~kg} \mathrm{~N} / \mathrm{fad}+$ ascobien $)$. A split plot design with three replications was used and combined analysis was done for the two experiments in each season. The results showed that there were clearly insignificant differences between rice and maize as a preceded summer crop on grain yield of wheat plants. The cropping sequence (maize or rice /Egyptian clover "fahl"/wheat) increased significantly all the studied wheat traits compared with the other copping systems in the two seasons. There were insignificant differences between application of $80 \mathrm{~kg} \mathrm{~N} / \mathrm{fad}$ and $60 \mathrm{~kg} \mathrm{~N} / \mathrm{fad}+$ ascobien for grain yield/fad in the two seasons. The optimum grain yield/fad was obtained by growing Egyptian clover "fahl" during transition period between preceded maize or rice in the summer season and wheat that fertilized by $60 \mathrm{~kg} \mathrm{~N} / \mathrm{fad}+$ ascobien in the winter season.
\end{abstract}

Keywords: Wheat, Maize, Rice, Egyptian clover, Cropping systems, $\mathbf{N}$ fertilizer.

\section{INTRODUCTION}

Wheat (Triticum aestivum L.) is the most important cereal crop because it is the staple food of the Egyptian people. However, it is primarily nitrogen $(\mathrm{N})$ - limited under production system in Egypt, Subba-Rao (1980) predicted the requirements for mineral $\mathrm{N}$ fertilizer will increase in the future. Now, the use of expensive chemical $\mathrm{N}$ fertilizers in Egypt is a limiting factor for the lowincome farmers and increases the cost of crop production where prices of chemical $\mathrm{N}$ fertilizers during a few years have increased. With the current technology for fertilizer production and the inefficient methods employed for fertilizer application, both the economic and ecological costs of fertilizer usage will eventually become prohibitive (Dixon and Wheeler, 1986). However, N is the most important nutrient element required for crop production. $\mathrm{N}$ deficiency is one of the major yield limiting factors for cereals (Shah et al., 2003). $\mathrm{N}$ is considered to be the most important factor in wheat production under Egyptian agricultural conditions (FAO, 2005).

Hence, there is an urgent need to maximize the efficient use of this element without excessive use of mineral $\mathrm{N}$ fertilizer by some agricultural practices through the suitable cropping sequences with using bio- fertilizers, which are natural, beneficial and ecologically friendly. Accordingly, the cropping system adopted by the farmer in these soils should be physically viable, sustainable, less exhaustive acceptable to farming community. Mixing species in cropping systems may lead to a range of benefits that are expressed on various space and time scales, from a short-term increase in crop yield and quality, to longer-term agroecosystem sustainability, up to societal and ecological benefits (Malezieux et al., 2009). Generally, the conventional cropping sequence in these areas is double cropping system (two crops per year). However, the preceded summer crop as rice (Oryza sativa L.) promoted degradation and inefficient use of natural resources, particularly soils and water (Gupta and Seth, 2007). Also, Hamd-Alla et al. (2015) revealed that wheat yield was reduced after maize (Zea mays L.) harvest. Consequently, if Egyptian agricultural production must be intensified, ways of making maximum use of land must be pursued without soil degradation and pollution. This necessitates the inclusion of catch crop as fodder crop such as fodder maize or Egyptian clover (Trifolium alexandrinum L.) after summer crop harvest and before wheat sowing which leading to triple cropping sequences.

Moreover, bio- fertilizers are natural, beneficial and ecologically friendly. Ascorbic acid and citric acid and their salts are widely known for their role as chelators and acidulants (Oktar et al., 2001 and Kim et al., 2006). Accordingly, there is need to explore the possibilities of using the expanding native sources of plant nutrition by adding 
antioxidants such as ascobien acid which containing ( $25 \%$ ascorbic acid $+13 \%$ citric acid) under such condition; especially the beneficial effects of ascobien acid upon growth have been reported on wheat (Ahmed, 2015). Therefore, the objective of this investigation was to decrease mineral $\mathrm{N}$ inputs of wheat crop.

\section{MATERIALS AND METHODS}

A two-year study was carried out at Sakha Agricultural Experiments and Research Station, Agricultural Research Center (A.R.C.), Kafr El Sheikh governorate $\left(31^{\circ} 06^{\prime} 42^{\prime \prime} \mathrm{N}, 30^{\circ} 56^{\prime} 45^{\prime \prime} \mathrm{E}, 17 \mathrm{~m}\right.$ a.s.1.), Egypt, during 2013/2014 and 2014/2015 to decrease mineral $\mathrm{N}$ inputs of wheat crop. The soil was clay textured. Chemical analysis of the soil $(0-$ $60 \mathrm{~cm}$ ) was done by Water, Soil and Environment Research Institute, ARC (Table 1). Chemical analysis of the soil was determined using the methods described by Jackson (1958) and Chapman and Pratt (1961). This study included two experiments begging with preceding summer crop (Rice or Maize), each experiment include 9 treatments which were the combinations of three cropping sequences (summer crop/Egyptian clover "fahl"/wheat, summer crop/fodder maize/wheat and summer crop/fallow/wheat) and three mineral $\mathrm{N}$ fertilizer rates $(80 \mathrm{~kg} \mathrm{~N} / \mathrm{fad}, 60 \mathrm{~kg} \mathrm{~N} / \mathrm{fad}+$ ascobien and $40 \mathrm{~kg} \mathrm{~N} /$ fad + ascobien).
Cultivars of all the tested crops were as follows: rice cv. Sakha 106, maize cv. S.C.128, Egyptian clover cv. Gemmiza 1 'fahl - one cut' and wheat cv. Giza 168. Wheat plots were tilled in two tillages, then it was fertilized by phosphor and potassium inform of calcium superphosphate $\left(\mathrm{P}_{2} \mathrm{O}_{5}, 15.5 \%\right)$ and potassium sulfate (48\%), respectively. Nitrogen fertilization was split in the form of urea $(46.5 \%)$ into two equal doses; the first dose was applied to the soil before the $1^{\text {st }}$ irrigation and the second one was applied before the $2^{\text {nd }}$ irrigation. Ascobien was added as a foliar application in two equal doses after one and two months from wheat sowing (200 g Ascbine acid $/ 150 \mathrm{~L}$ water) for each dose. Furrow irrigation is the irrigation system in the area. Recommended cultural practices for growing all crops were implemented as provided by the Egyptian Ministry of Agriculture. Dates of sowing and harvesting of all the tested crops are presented in Table (2).

At 60 and 120 days from wheat sowing, the following traits were measured from each sub plot: Dry weight $/ \mathrm{m}^{2}(\mathrm{~g})$ and leaf area index (LAI). Flag leaf area $\left(\mathrm{cm}^{2}\right)$ was measured at 120 days from wheat sowing then calculated as a mean of ten flag leaves area from each sub plot. At harvest, the following traits were measured from each sub plot: plant height $(\mathrm{cm})$, number of spikes $/ \mathrm{m}^{2}$, number of grains/spike. Grain yield/fad (ardab) was recorded on the basis of experimental plot area by harvesting all plants of each sub plot.

Table 1: Chemical properties of soil $(0-60 \mathrm{~cm}$ depth) during different periods during the year.

\begin{tabular}{lccc}
\hline Traits & & Maize experiment & Rice experiment \\
\hline Before planting the experiment & $\mathrm{N}(\mathrm{ppm})$ & 20 & 20 \\
\cline { 2 - 4 } & $\mathrm{P}(\mathrm{ppm})$ & 36 & 36 \\
\cline { 2 - 4 } & $\mathrm{K}(\mathrm{ppm})$ & 656 & 656 \\
\hline After maize or rice harvesting & $\mathrm{N}(\mathrm{ppm})$ & 32 & 26 \\
\cline { 2 - 4 } & $\mathrm{P}(\mathrm{ppm})$ & 51 & 43 \\
\hline After Egyptian clover cutting & $\mathrm{K}(\mathrm{ppm})$ & 704 & 684 \\
\cline { 2 - 4 } & $\mathrm{N}(\mathrm{ppm})$ & 55 & 65 \\
\cline { 2 - 4 } & $\mathrm{P}(\mathrm{ppm})$ & 72 & 811 \\
\hline After fodder maize harvesting & $\mathrm{K}(\mathrm{ppm})$ & 848 & 34 \\
\cline { 2 - 4 } & $\mathrm{P}(\mathrm{ppm})$ & 34 & 759 \\
\cline { 2 - 4 }
\end{tabular}

Table 2: Dates of sowing and harvesting of all the tested crops in the two seasons.

\begin{tabular}{lcccc}
\hline \multirow{2}{*}{ Crops } & \multicolumn{2}{c}{$\mathbf{2 0 1 4}$} & \multicolumn{2}{c}{$\mathbf{2 0 1 5}$} \\
\hline Rice & Sowing & Harvested & sowing & harvested \\
\cline { 2 - 5 } Maize & 19 May & 10 September & 10 May & 1 September \\
\hline Forage berseem & 20 May & 10 September & 10 May & 1 September \\
\hline Fodder Maize & 20 September & 24 November & 11 September & 13 November \\
\hline Wheat & 20 September & 24 November & 11 September & 13 November \\
\hline
\end{tabular}


The treatments were assigned at random in each experiment in split plot design in three replications and a combined analysis for the two experiments was done in each season. Crop sequences (forage crops) were arranged at random in the main plots, whereas mineral $\mathrm{N}$ fertilizer rates were randomly allocated in sub plots. The sub plots area was $7 \times 4 \mathrm{~m}$. Data was statically analyzed according to Gomez and Gomez (1984).

\section{RESUITS AND DISCUSSION}

\section{Growth characters:}

Data in Tables 3 and 4 show that preceding crop had a significant effect on Dry weight $\left(\mathrm{g} / \mathrm{m}^{2}\right)$ of wheat at 60 and 120 days and plant height in both seasons as well as flag leaf area $\left(\mathrm{cm}^{2}\right)$ at heading in the second season. Application of rice as preceding crop resulted in a significant increase in Dry weight $\left(\mathrm{g} / \mathrm{m}^{2}\right)$ of wheat compared with maize in the two seasons. The inverse was true in flag leaf area and plant height. LAI did not significantly affected by preceding crop at the two sampling dates in both seasons. It is likely that residual effects of rice enhanced complementary positive interactions in soil than those of maize which reflected positively on different biological processes in the rhizosphere of wheat and in turn increased Dry weight per unit area. These results may be attributed to rice allowed the transport of oxygen into the rhizosphere thus providing a habitat for both aerobic and anaerobic bacteria involved in redox reactions of the $\mathrm{C}, \mathrm{N}$ and $\mathrm{S}$ cycle (Sessitsch et al., 2012). Meanwhile, maize is supportive for aerobic degradation of organic matter to $\mathrm{CO}_{2}$ (Breidenbach et al., 2017).

According to cop sequences data in table (3\& 4) showed that there was a significant effect on all growth characters in both seasons.It seems that Egyptian clover gave the highest wheat dry weight $/ \mathrm{m}^{2}$, LAI, flag leave area and plant height compared with the others. These results may be due to the beneficial effect of decomposition of Egyptian clover residues that altered positively the dynamics of organic matter turnover and the rate of nutrient cycling within the soil. It is known that soil organic matter accumulation improve soil quality through its extensive impacts on soil physical, chemical and biological properties (Johnston et al., 2009). Such effect was expected because of soil $\mathrm{N}$ availability was increased as result of a mix of living rhizobia and dead Egyptian clover roots in the experimental soil before wheat sowing (Table 1). Accordingly, the rate of photosynthesis which reflected positively on dry weight of whole plant could be maintained high during grain filling in later periods of senescence as a consequence of increase LAI. On the other hand, residues effects of fodder maize has influenced negatively soil chemical properties (Table 1) and resulted in unfavorable environmental conditions between wheat plants for basic growth resources.

The results show that the highest dry weight $/ \mathrm{m}^{2}$, LAI, flag leave area and plant height was obtained with application of $80 \mathrm{~kg} \mathrm{~N} /$ fad followed $60 \mathrm{~kg} \mathrm{~N} / \mathrm{fad}$ + ascobien (Table $3 \& 4$ ). It is important to mention that there were insignificant differences between the highest and the medium mineral $\mathrm{N}$ rate for LAI. Obviously, ascobien that is a simulative compound containing (13\% ascorbic acid, $25 \%$ citric acid) enhanced cell division and enlargement which reflected positively on leaf area. Ascobien is a product of D-glucose metabolism which effected nutrition cycles activity in higher plants and plays an important role in the electron transport system (Helsper et al., 1982). Thus, ascorbic +citric acids appeared to act in a concert which indicates a complete set of antioxidant defense system. These results are in harmony with those obtained by AbdEl-Hameed (2004), bakry (2013), El Tahan (2015) and Ahmed (2015). On other hand, application of 40 $\mathrm{kg} \mathrm{N} / \mathrm{fad}+$ ascobien recorded the lowest values for growth characters in the two seasons. These results may be due to $\mathrm{N}$ availability did not satisfy wheat requirement for growth and development.

\section{Grain yield and its attributes:}

Data in (Table 5) shows that preceding summer crop had a significant effect on number of grains $/ \mathrm{m}^{2}$, while number of grains/spike and grain yield (ardab/fed.) did not affect. Preceded maize crop caused significant decreases in number of spikes $/ \mathrm{m}^{2}$ compared to those of preceded rice crop. Accordingly, it is expected that growth resources such as water and soil nutrients were more relatively absorbed and converted to crop biomass during growth and development stages of wheat plants that followed rice than wheat after maize harvest. It is known that the photosynthetic rate/unit area of leaf depends on the development and maintenance of the photosynthetic system (Farquhar et al., 1980).

Cropping sequences affected significantly number of spikes $/ \mathrm{m}^{2}$, number of grains $/$ spike and grain yield/fad in the two seasons except number of grains/spike in the first one (Table 4\&5). Egyptian clover in the transition period gave the highest number of spikes $/ \mathrm{m}^{2}$, number of grains/spike and grain yield/fad compared with the others. These results probably due to the residual effects of Egyptian clover increased soil N, P and K availability (Table 1) for wheat growth and development that affected positively the yield attributes of wheat compared with the others. These results reveal that residual effects of Egyptian clover enhanced efficiency of photosynthetic process of wheat crop which reflected on yield attributes of wheat.

Mineral $\mathrm{N}$ fertilizer rate had significant effect on number of spikes $/ \mathrm{m}^{2}$, number of grains/spike and grain yield/fad in the two seasons (Table 4\&5). Wheat plants which fertilized with $80 \mathrm{kgN} / \mathrm{fad}$ gave the highest values of number of spikes $/ \mathrm{m}^{2}$, number of grains/spike and grain yield/fad in the two seasons. 
Table 3: Dry weight/plant (gm/m2) and Leaf area index (LAI) as affected by crop sequences and nitrogen fertilization in 2014 and 2015 seasons.

\begin{tabular}{|c|c|c|c|c|c|c|c|c|}
\hline \multirow[t]{4}{*}{ Factor } & \multicolumn{4}{|c|}{ Dry weight (g/m2) } & \multicolumn{4}{|c|}{ LAI } \\
\hline & 2014 & 2014 & 2015 & 2015 & 2014 & 2014 & 2015 & 2015 \\
\hline & \multicolumn{4}{|c|}{ Days after sowing } & \multicolumn{4}{|c|}{ Days after sowing } \\
\hline & 60 & 120 & 60 & 120 & 60 & 120 & 60 & 120 \\
\hline \multicolumn{9}{|l|}{ P.C (P) } \\
\hline Rice & $690 \quad \mathrm{a}$ & $2483.6 \mathrm{a}$ & 796.4 & $2537.2 \mathrm{a}$ & 3.25 & 5.72 & 8.26 & 9.56 \\
\hline Maize & $682.9 \mathrm{~b}$ & $2142.2 \mathrm{~b}$ & 768.1 & $2351.6 \mathrm{~b}$ & 3.45 & 3.04 & 6.51 & 7.58 \\
\hline f-test & $* *$ & $* *$ & $\mathrm{NS}$ & $* *$ & NS & $\mathrm{NS}$ & $\mathrm{NS}$ & $\mathrm{NS}$ \\
\hline \multicolumn{9}{|l|}{ Forage crop $(\mathrm{F})$} \\
\hline Clover & $708.9 \mathrm{a}$ & $2427.1 \mathrm{a}$ & $799.6 \mathrm{a}$ & $2530.9 \mathrm{a}$ & $3.65 \mathrm{a}$ & $5.21 \mathrm{a}$ & $7.23 \mathrm{a}$ & $9.18 \mathrm{a}$ \\
\hline Maize & $671.5 \mathrm{~b}$ & $2216.8 \mathrm{c}$ & $764.8 \mathrm{c}$ & $1359.6 \mathrm{c}$ & $3.16 \mathrm{~b}$ & $4.14 \mathrm{~b}$ & $6.22 \mathrm{~b}$ & $7.93 \mathrm{~b}$ \\
\hline Non & $678.9 \mathrm{~b}$ & $2294.8 \mathrm{~b}$ & $782.3 \mathrm{~b}$ & $2442.7 \mathrm{~b}$ & $3.25 \mathrm{~b}$ & $5.27 \mathrm{a}$ & $6.57 \mathrm{ab}$ & $8.6 \mathrm{a}$ \\
\hline f-test & $* *$ & $* *$ & $* *$ & $* *$ & $* *$ & $* *$ & $* *$ & $* *$ \\
\hline \multicolumn{9}{|l|}{$\mathrm{N} /$ fed. (N) } \\
\hline 80 & $731.3 \mathrm{a}$ & $2429.0 \mathrm{a}$ & $823.7 \mathrm{a}$ & $2523.3 \mathrm{a}$ & $3.96 \mathrm{a}$ & $5.47 \mathrm{a}$ & $8.87 \mathrm{a}$ & $8.5 \mathrm{a}$ \\
\hline $60+$ Ascobine & $691.0 \mathrm{~b}$ & $2333.2 \mathrm{~b}$ & $775.6 \mathrm{~b}$ & $2453.1 \mathrm{~b}$ & $3.53 \mathrm{~b}$ & $4.79 \mathrm{ab}$ & $6.91 \mathrm{ab}$ & $8.7 \mathrm{a}$ \\
\hline $40+$ Ascoobine & $637.1 \mathrm{c}$ & $2176.6 \mathrm{c}$ & $747.4 \mathrm{c}$ & $2356.8 \mathrm{c}$ & $2.57 \mathrm{c}$ & $4.36 \mathrm{~b}$ & $6.39 \mathrm{~b}$ & $7.7 \mathrm{~b}$ \\
\hline f-test & $* *$ & $* *$ & $* *$ & $* *$ & $* *$ & $* *$ & $* *$ & $* *$ \\
\hline \multicolumn{9}{|l|}{ Interaction } \\
\hline$P \times F$ & $* *$ & $* *$ & $* *$ & $* *$ & $*$ & $* *$ & $* *$ & $* *$ \\
\hline $\mathrm{P} \times \mathrm{N}$ & N.S & $* *$ & N.S & $* *$ & $* *$ & $* *$ & $* *$ & $*$ \\
\hline $\mathrm{F} \times \mathrm{N}$ & N.S & $* *$ & $* *$ & $*$ & $* *$ & $*$ & $\mathrm{NS}$ & $* *$ \\
\hline $\mathrm{PXFXN}$ & $*$ & $* *$ & $* *$ & $* *$ & $* *$ & $* *$ & $\mathrm{NS}$ & $* *$ \\
\hline
\end{tabular}

Table 4: Flag leaf area (cm2), Plant height $(\mathrm{cm})$, Spike no./m2 and grain no./spike as affected by crop sequences and nitrogen fertilization in 2014 and 2015 seasons.

\begin{tabular}{|c|c|c|c|c|c|c|c|c|}
\hline \multirow[t]{2}{*}{ Factor } & \multicolumn{2}{|c|}{$\begin{array}{l}\text { Flag leave area } \\
(\mathrm{cm} 2)\end{array}$} & \multicolumn{2}{|c|}{$\begin{array}{l}\text { Plant height } \\
\text { (cm) }\end{array}$} & \multicolumn{2}{|c|}{ Spikes No./m2 } & \multicolumn{2}{|c|}{ Grains No./sike } \\
\hline & 2014 & 2015 & 2014 & 2015 & 2014 & 2015 & 2014 & 2015 \\
\hline \multicolumn{9}{|l|}{ P.C (P) } \\
\hline Rice & 22.2 & $22.66 \mathrm{~b}$ & $78.02 \mathrm{~b}$ & $80.31 \mathrm{~b}$ & $471.32 \mathrm{a}$ & $448.62 \mathrm{a}$ & 52.05 & 54.17 \\
\hline Maize & 21.76 & $24.6 \mathrm{a}$ & $86.66 \mathrm{a}$ & $86.35 \mathrm{a}$ & $390.37 \mathrm{~b}$ & $401.67 \mathrm{~b}$ & 52.09 & 56.42 \\
\hline f-test & NS & $* *$ & $* *$ & $* *$ & $* *$ & $* *$ & NS & NS \\
\hline \multicolumn{9}{|l|}{ Forage crop $(\mathrm{F})$} \\
\hline Clover & $23.88 \mathrm{a}$ & $25.32 \mathrm{a}$ & $84.85 \mathrm{a}$ & $85.74 \mathrm{a}$ & $500.2 \mathrm{a}$ & $502.76 \mathrm{a}$ & 53.48 & $57.45 \mathrm{a}$ \\
\hline Maize & $21.08 \mathrm{~b}$ & $22.52 \mathrm{~b}$ & $80.54 \mathrm{c}$ & $81.78 \mathrm{~b}$ & $382.59 \mathrm{c}$ & $354.86 \mathrm{c}$ & 51.63 & $54.48 \mathrm{~b}$ \\
\hline Non & $20.97 \mathrm{~b}$ & $23.05 \mathrm{~b}$ & $81.62 \mathrm{~b}$ & $82.47 \mathrm{~b}$ & $409.75 \mathrm{~b}$ & $417.81 \mathrm{~b}$ & 51.1 & $53.95 \mathrm{~b}$ \\
\hline f-test & $* *$ & $* *$ & $* *$ & $* *$ & $* *$ & $* *$ & NS & $* *$ \\
\hline \multicolumn{9}{|l|}{ N/fed. (N) } \\
\hline 80 & $24.55 \mathrm{a}$ & $26.21 \mathrm{a}$ & $85.33 \mathrm{a}$ & $85.85 \mathrm{a}$ & $472.18 \mathrm{a}$ & $482.98 \mathrm{a}$ & $54.35 \mathrm{a}$ & $58.39 \mathrm{a}$ \\
\hline $60+$ Ascobine & $23.4 \mathrm{~b}$ & $25.33 \mathrm{a}$ & $83.05 \mathrm{~b}$ & $84.5 \mathrm{~b}$ & $435.93 \mathrm{~b}$ & $427.53 \mathrm{~b}$ & $52.86 \mathrm{~b}$ & $56.03 \mathrm{~b}$ \\
\hline $40+$ Ascoobine & $17.98 \mathrm{c}$ & $19.35 \mathrm{~b}$ & $78.64 \mathrm{c}$ & $79.65 \mathrm{c}$ & $384.42 \mathrm{c}$ & $364.91 \mathrm{c}$ & $48.99 \mathrm{c}$ & $51.47 \mathrm{c}$ \\
\hline f-test & $* *$ & $* *$ & $* *$ & $* *$ & $* *$ & $* *$ & $* *$ & $* *$ \\
\hline \multicolumn{9}{|l|}{ Interaction } \\
\hline $\mathrm{PX} F$ & $* *$ & $* *$ & $* *$ & $* *$ & $* *$ & $* *$ & N.S & $* *$ \\
\hline $\mathrm{PX} \mathrm{N}$ & $* *$ & $*$ & $* *$ & $* *$ & $* *$ & N.S & N.S & N.S \\
\hline $\mathrm{F} X \mathrm{~N}$ & N.S & N.S & N.S & $*$ & $*$ & N.S & $* *$ & $* *$ \\
\hline P X F X N & $* *$ & $*$ & $* *$ & $* *$ & $* *$ & $* *$ & N.S & $* *$ \\
\hline
\end{tabular}

*, ** and NS indicate $\mathrm{P}<0.05, \mathrm{P}<0.01$ and not significant, respectively. In each factor, means followed by a common letter are not significantly different at the $5 \%$ level by DMRT 
Table 5: Grain yield (ardab/fed.) of wheat cv. Giza 168 as affected by crop sequences and nitrogen fertilization and their interactions in 2014 and 2015 seasons.

\begin{tabular}{|c|c|c|c|c|c|c|c|c|c|}
\hline \multirow{3}{*}{ P.C } & \multirow{3}{*}{ Forage } & \multicolumn{4}{|c|}{2014} & \multicolumn{4}{|c|}{2015} \\
\hline & & \multicolumn{3}{|c|}{ N. Fertilization } & \multirow[t]{2}{*}{ Mean } & \multicolumn{3}{|c|}{ N. Fertilization } & \multirow[t]{2}{*}{ Mean } \\
\hline & & 80 & $\begin{array}{c}60+ \\
\text { Ascobine }\end{array}$ & $\begin{array}{c}40+ \\
\text { Ascobine }\end{array}$ & & 80 & $\begin{array}{c}60+ \\
\text { Ascbine }\end{array}$ & $\begin{array}{c}40+ \\
\text { Ascbine }\end{array}$ & \\
\hline & & \multicolumn{3}{|c|}{ Mean ( PXFXN) } & $(\mathrm{PXF})$ & \multicolumn{3}{|c|}{ Mean ( PXFXN) } & (PXF) \\
\hline \multirow[t]{3}{*}{ Rice } & Clover & $19.84 \mathrm{a}$ & $19.57 \mathrm{a}$ & $16.67 \mathrm{bcd}$ & 18.69 & $21.5 \mathrm{a}$ & $21.45 \mathrm{a}$ & $17.46 \mathrm{f}$ & $20.14 \mathrm{~A}$ \\
\hline & Maize & $19.61 \mathrm{a}$ & $16.15 \mathrm{~cd}$ & $16.76 \mathrm{bcd}$ & 17.51 & $20.27 \mathrm{abc}$ & $19.92 \mathrm{bc}$ & $17.25 \mathrm{f}$ & $19.15 \mathrm{~B}$ \\
\hline & Non & $18.58 \mathrm{ab}$ & $18.15 \mathrm{abc}$ & $13.46 \mathrm{e}$ & 16.73 & $20.68 \mathrm{ab}$ & $18.98 \mathrm{cde}$ & $15.72 \mathrm{~g}$ & $18.46 \mathrm{C}$ \\
\hline \multirow[t]{4}{*}{ Maize } & Clover & $20.25 \mathrm{a}$ & $20.18 \mathrm{a}$ & $14.93 \mathrm{de}$ & 18.45 & $21.08 \mathrm{ab}$ & $20.86 \mathrm{ab}$ & $18.07 \mathrm{ef}$ & $20 \mathrm{~A}$ \\
\hline & Maize & $19.18 \mathrm{a}$ & $18.6 \mathrm{ab}$ & $11.16 \mathrm{f}$ & 16.31 & $19.69 \mathrm{bcd}$ & 18.4def & $12.2 \mathrm{~h}$ & $16.76 \mathrm{D}$ \\
\hline & Non & $19.54 \mathrm{a}$ & $18.73 \mathrm{ab}$ & $13.12 \mathrm{e}$ & 17.13 & $20.34 \mathrm{abc}$ & $19.91 \mathrm{bc}$ & $14.43 \mathrm{~g}$ & $18.23 \mathrm{C}$ \\
\hline & & & \multicolumn{2}{|c|}{ Mean $(\mathrm{PXN})$} & (P) & \multicolumn{3}{|c|}{ Mean $(\mathrm{PXN})$} & (P) \\
\hline Rice & & $19.34 \mathrm{a}$ & $17.96 \mathrm{~b}$ & $15.63 \mathrm{c}$ & 17.64 & $20.82 \mathrm{a}$ & $20.12 \mathrm{ab}$ & $16.81 \mathrm{c}$ & 19.25 \\
\hline \multirow[t]{5}{*}{ Maize } & & $19.66 \mathrm{a}$ & $19.17 \mathrm{a}$ & $13.07 \mathrm{~d}$ & 17.3 & $20.37 \mathrm{ab}$ & $19.72 \mathrm{~b}$ & $14.9 \mathrm{~d}$ & 18.33 \\
\hline & & \multicolumn{3}{|c|}{ Mean $(\mathrm{FXN})$} & (F) & \multicolumn{3}{|c|}{ Mean (FXN) } & (F) \\
\hline & Clover & 20.04 & 19.87 & 15.8 & $18.57 \mathrm{~A}$ & $21.29 \mathrm{a}$ & $21.16 \mathrm{a}$ & $17.76 \mathrm{~d}$ & $20.07 \mathrm{~A}$ \\
\hline & Maize & 19.4 & 17.38 & 13.96 & $16.91 \mathrm{~B}$ & $19.98 \mathrm{bc}$ & $19.16 \mathrm{c}$ & $14.73 \mathrm{e}$ & $18.34 \mathrm{~B}$ \\
\hline & Non & 19.06 & 18.44 & 13.29 & $16.93 \mathrm{~B}$ & $20.51 \mathrm{ab}$ & $19.44 \mathrm{c}$ & $15.07 \mathrm{e}$ & $17.95 \mathrm{~B}$ \\
\hline Mean & & $19.5 \mathrm{~A}$ & $18.56 \mathrm{~B}$ & $14.35 \mathrm{C}$ & & $20.59 \mathrm{~A}$ & $19.92 \mathrm{~B}$ & $15.85 \mathrm{C}$ & \\
\hline
\end{tabular}

Means followed by a common letter are not significantly different at the $5 \%$ level by DMRT.

These results probably due to the adequate mineral $\mathrm{N}$ rate $(80 \mathrm{~kg} \mathrm{~N} /$ fad $)$ facilitated the tillering ability of the plants and resulted in greater spike population (Jan and Khan, 2000). On other hand, application of $40 \mathrm{~kg} \mathrm{~N} / \mathrm{fad}+$ ascobien recorded the lowest number of spikes $/ \mathrm{m}^{2}$, number of grains/spike and grain yield/fad in the two seasons (Table 4). These results may be due to the shortage of $\mathrm{N}$ availability for wheat growth and development, which affected negatively the plant to produce more number of grains/spike. It is known that assimilates availability from flag leaf developed under high $\mathrm{N}$ supply determined the number of fertile florets at anthesis and in turn final grain number and that would be key trait to improve wheat yield without changing the anthesis date (Kumari, 2011). Similar results were obtained by El-Hag (2012) who found that increase in mineral $\mathrm{N}$ rate resulted in reduction in mortality of tillers which reflected on number of tillers from the main stem.

All the interactions affected significantly most the studied wheat traits in both seasons (Table 3, $4 \& 5)$.

The interactions of grain yield (ardab/fed.): Interaction between preceded summer crops and cropping sequences

Grain yield/fad wasaffected significantly by the interaction between preceded summer crops and cropping sequences in the two seasons (Table 5). With regardless to the summer crop, growing Egyptian clover in the transition period achieved the highest grain yield/fad compared with the others. These results may be due to growing Egyptian clover in the transition period improved soil nutrient dynamics after summer maize or rice harvest. So, it may be possible that residual effects of Egyptian clover disrupted soil aggregates and increased aeration for wheat growth and development compared with others. These results show that each of these two factors act dependently on grain yield/fad.

Interaction between preceded summer crops and mineral $\mathbf{N}$ fertilizer rates

Grain yield/fad wasaffected significantly by the interaction between preceded summer crops and mineral $\mathrm{N}$ fertilizer rates in the two seasons (Table $5)$. With regardless to the summer crop, application of the highest mineral $\mathrm{N}$ fertilizer rate $(80 \mathrm{~kg} \mathrm{~N} / \mathrm{fad})$ to wheat plants achieved the highest grain yield/fad compared with the others. These results could be justified with logic that $\mathrm{N}$ availability satisfied wheat requirement for growth and development, which enabled the plant to produce more number of grains/spike. On the other hand, application of $40 \mathrm{~kg}$ $\mathrm{N} / \mathrm{fad}+$ ascobien did not integrate with summer crops to have sufficient supply of $\mathrm{N}$ for the plant which achieved unacceptable source and sink capacity. These data indicate that there was effect of summer crops $\mathrm{x}$ mineral $\mathrm{N}$ fertilizer rates on grain yield/fad.

Interaction between cropping sequences and mineral $\mathbf{N}$ fertilizer rates

Grain yield/fad wasaffected significantly by the interaction between cropping sequences and mineral $\mathrm{N}$ fertilizer rates in the two seasons (Table 5). Application of $80 \mathrm{~kg} \mathrm{~N} / \mathrm{fad}$ or $60 \mathrm{~kg} \mathrm{~N} / \mathrm{fad}+$ ascobien to wheat plants that followed Egyptian clover recorded the highest grain yield/fad compared with the others. These results may be due to $60 \mathrm{~kg} \mathrm{~N} / \mathrm{fad}+$ ascobien interacted positively with residues effects of Egyptian clover to reach the highest mineral $\mathrm{N}$ fertilizer rate effect on grain yield/fad. These data show that mineral $\mathrm{N}$ fertilizer rates responded differently to cropping sequences for grain yield/fad. 
Interaction among preceded summer crops, cropping sequences and mineral $\mathbf{N}$ fertilizer rates

Grain yield/fad wasaffected significantly by the interaction among preceded summer crops, crop sequences and mineral $\mathrm{N}$ fertilizer rates in the two seasons (Table 5). With regardless to the summer crop, the optimum grain yield/fad was observed by growing wheat plants after Egyptian clover and fertilized with $80 \mathrm{~kg} \mathrm{~N} / \mathrm{fad}$ or $60 \mathrm{~kg} \mathrm{~N} /$ fed + ascobien. These data reveal that there was effect of summer crops $\mathrm{x}$ cropping sequences $\mathrm{x}$ mineral $\mathrm{N}$ fertilizer rates on grain yield/fad.

\section{CONCLUSION}

Our results showed that intensive cropping system (maize or rice/ Egyptian clover/wheat) with application of ascobien acid could be an alternative way to decrease mineral $\mathrm{N}$ inputs of wheat by about $25 \% \mathrm{~N}$ of the recommended mineral $\mathrm{N}$ fertilizer rate of wheat plants.

\section{REFERENCES}

Abd-El-Hameed A.M., Sarhan S.H. and Abd ElSalam H.Z. 2004. Evaluation of some organic acids as foliar application on growth, yield and some nutrient contents of wheat. J. Agric. Sci., Mansoura Univ., 29(5): 2475 - 2481.

Ahmed K.M.H.H. 2015. Effect of some agriculture practices on wheat. M.Sc. Thesis, Agron. Dept., Fac. Agric., Kafrelsheikh Univ., Egypt.

Bakry B.A, Elewal T.A., El-Kramany M.F. and Wali A.M. 2013. Effect of humic acid and ascorbic acids foliar application on yield and yield components of two wheat cultivars grown under newly reclaimed sandy soil. Int. J. Agron. Plant. Prod., 4(6): 1125 - 1133.

Breidenbach B., Brenzinger K., Brandt F.B., Blaser M.B. and Conrad R. 2017. The effect of crop rotation between wetland rice and upland maize on the microbial communities associated with roots. Plant Soil, DOI 10.1007/s11104-0173351-5.

Chapman H.D. and Pratt P.E. 1961. Methods of Analysis for Soil, Plant and Water.Division Agric. Sci., California Univ., U.S.A.

Dixon R.O.D. and Wheeler C.T. 1986. Nitrogen Fixation in Plants. Blackie, Glasgow, United Kingdom.

El-Hag Dalia A.A. 2012. Effect of planting date and nitrogen level on yield and quality of bread and durum wheat. Ph.D. Thesis, Agron. Dept., Fac. Agric., Kaferelshikh Univ., Egypt.

El Tahan Amira M.A. 2015. Effect of some promoting substances with different fertilizers on growth and yield of wheat under conditions of calcareous and clay soils. M.Sc. Thesis, Agron. Dept., Fac. Agric., Kafrelsheikh Univ., Egypt.
Farquhar G.D., Von Caemmerer S. and Berry J.A. 1980. A biochemical model of photosynthetic $\mathrm{CO} 2$ assimilation in leaves of $\mathrm{C} 3$ species.Planta, 149: $78-90$.

FAO. 2005. Fertilizer use by crop in Egypt. Food and Agricultural Organization of the United Nations, Rome.

Gomez K.N and Gomez A.A. 1984. Statistical Procedures for Agricultural research.An International Rice Research Institute Book John Willey and Sons.Ine., New Yourk.

Gupta R. and Seth A. 2007. A review of resource conserving technologies for sustainable management of the rice-wheat cropping systems of the Indo-Gangetic Plains (IGP). Crop Protection, 26: 436 - 447.

Hamd-Alla W.A., Shalaby E.M., Dawood R.A. and Zohry A.A. 2015. Effect of crop sequence and nitrogen fertilization on productivity of wheat. Elixir Int. J. Agric., 88: 36215 - 36222.

Helsper J.P., Kagan L., Maynard J.M. and Loewus F.A. 1982. L-Ascorbic acid biosynthesis in Ochromonasdanica.Plant physiol., 67: 485 468.

Jackson M.L. 1958. Soil Chemical Analysis, Prentice Hall, EnglwoodCliffis, New Jersy.

Jan M.T. and Khan S. 2000. Response of wheat yield components to type of $\mathrm{N}$ - fertilizer, their levels and application time. Pak. J.Bio. Sci., 3(8): 1227 -1230 .

Johnston A.E., Poulton P.R. and Coleman K. 2009. Soil organic matter: Its importance in sustainable agriculture and carbon dioxide fluxes. Adv. Agron., 101: 1 - 57.

Kim S., Lee K., Park J., Lee H. and Hwang I., 2006. Effect of natural antioxidants on stored freezedried food product formulated using horse mackerel (Trachurustrachurus). J. Sci. Techno., 41: $90-95$.

Kumari S. 2011. Yield response of uniculm wheat (Triticum aestivum L.) to early and late application of nitrogen: flag leaf development and senescence. J. Agric. Sci., 3(1): 170 - 182.

Malezieux E., Crozat Y., Dupraz C., Laurans M., Makowski D., Ozier-Lafontaine H., Rapidel B., Tourdonnet S. and Valantin-Morison M. 2009. Mixing plant species in cropping systems: concepts, tools and Models.A review Agron.for Sustainable Dev., 29: 43-62.

Oktar G.L., Sinci V., Kalayciogilu S., Soncul H., Gokgoz L., Halit V. and Ersoz A. 2001. Biochemical and hemodynamic effects of ascorbic acid and alpha-tocopherol in coronary artery surgery. Scandinavian j. clinical and laboratory investigation, 61:621-630. 
Sessitsch A., Hardoim P., Döring J., Weilharter A., Krause A., Woyke T., Mitter B., Hauberg-Lotte L., Friedrich F., Rahalkar M., Hurek T., Sarkar A., Bodrossy L., Van Overbeek L., Brar D., Van Elsas J. and Reinhold-Hurek B. 2012. Functional characteristics of an endophyte community colonizing rice roots as revealed by metagenomic analysis. Mol Plant-Microbe Interactions, 25: 28-36.
Shah Z., Shah S.H., Peoples M.B., Schwenke G.D. and Hrridge D.F. 2003. Crop residue and fertilizer $\mathrm{N}$ effects on nitrogen fixation and yields of legume-cereal rotations and soil organic fertility. Field Crops Res., 83: $1-11$.

Subba-Rao N.S. 1980. Crop responses to microbial inoculation. In: SubbaRao N. S. (ed) Recent advances in nitrogen fixation. Edward Arnold, London, pp. $406-420$.

\section{الملخص الاعربي}

\section{تأثير التعاقب التقليدى والمكثف على إنتاجية القمح تحث معدلات مختلفة من التسميد النيتروجينى}

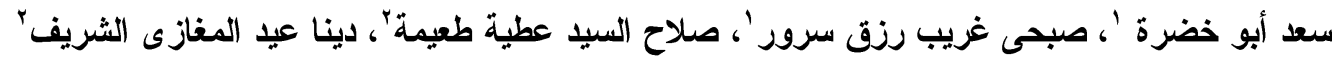

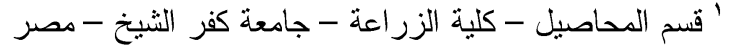

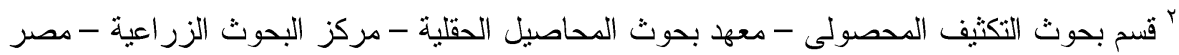

تم تتفيذ دراسة لمدة سنتين بمحطة البحوث و التجارب بمركز البحوث الزر اعبة بسخا بمحافظة كفر الثيخ - مصر

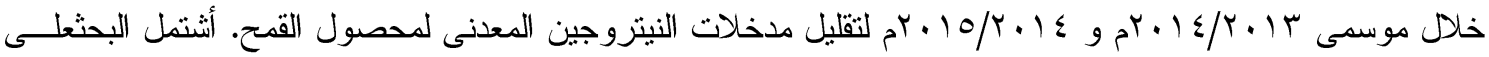
تجربتين حقليتين تبدأ كل تجربه فى الموسم الصيفى (الأرز أو الذرة الثامية) وتنتنمل كل تجربه على 9 معاملات وهى

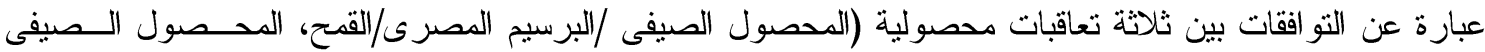

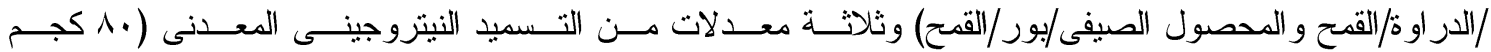

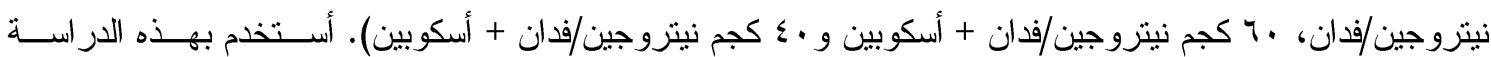
تصميم القطع المنشقة مره و احده فى ثلاث مكررات مع عمل تحليل (مشترك) للتجربتين كل عام.

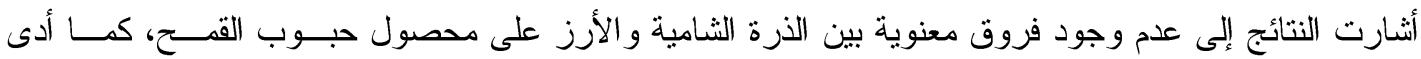

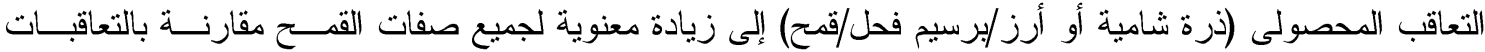
المحصولية الأخرى فى كلا الموسمين.

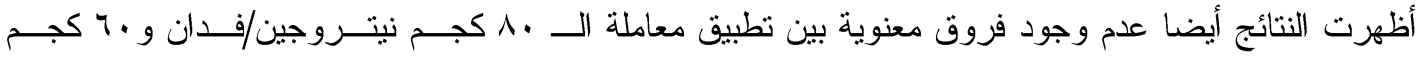
نيتروجين/فدان + أسكوبين على محصول حبوب القمح فى كلا الموسمين. تم الحصول على أفضل محصول حبوب قمح للفدان بزر اعة البرسيم الفحل فى الفترة البينية بين محصول الذرة الثشامية او الأرز السابق فى الموسم الصيفى والقمــح

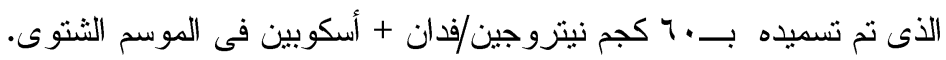

الكلمات الدالة: القمح - الذرة الثامية - الأرز - البرسيم المصرى - أنظمة محصولية - التسميد النيتروجينى. 